NBER WORKING PAPER SERIES

\title{
INTERNATIONAL RESERVE HOLDINGS WITH SOVEREIGN RISK AND COSTLY TAX COLLECTION
}

\author{
Joshua Aizenman \\ Nancy Marion \\ Working Paper 9154 \\ http://www.nber.org/papers/w9154 \\ NATIONAL BUREAU OF ECONOMIC RESEARCH \\ 1050 Massachusetts Avenue \\ Cambridge, MA 02138 \\ September 2002
}

We would like to thank Yeonho Lee and seminar participants at UCSC, Ben-Gurion University, and the Korea and The World Economy Conference [Seoul, July 2002, jointly organized by AKES, KDI, and RICE] for helpful comments. The views expressed herein are those of the authors and not necessarily those of the National Bureau of Economic Research.

(C) 2002 by Joshua Aizenman and Nancy Marion. All rights reserved. Short sections of text, not to exceed two paragraphs, may be quoted without explicit permission provided that full credit, including $\odot$ notice, is given to the source. 
International Reserve Holdings With Sovereign Risk and Costly Tax Collection

Joshua Aizenman and Nancy Marion

NBER Working Paper No. 9154

September 2002

JEL No. F15, F32, F34

\begin{abstract}
$\underline{\text { ABSTRACT }}$
This paper analyzes the international reserve-holding behavior of developing countries. It shows that political-economy considerations modify the optimal reserve level determined by efficiency criteria. A country characterized by volatile output, inelastic demand for fiscal outlays, high tax collection costs and sovereign risk will want to accumulate international reserves as well as external debt. Efficiency considerations imply that reserves are optimal when the benefits they provide for intertemporal consumption and distortion smoothing equal the costs of acquiring them. However, a greater chance of opportunistic behavior by future policy makers reduces the demand for international reserves and increases external borrowing. Political corruption also reduces optimal reserve holdings. We provide some evidence to support these findings. Consequently, the debt-toreserves ratio may be less useful as a vulnerability indicator. A version of the Lucas Critique suggests that if a high debt-to-reserves ratio is a symptom of opportunistic behavior, a policy recommendation to increase international reserve holdings may be welfare-reducing.
\end{abstract}

Joshua Aizenman

Department of Economics

University of California,Santa Cruz

1156 High St., Santa Cruz, CA 95064

and NBER

jaizen@cats.ucsc.edu
Nancy P. Marion

Department of Economics

Dartmouth College

Hanover, NH, 03755

m.p.marion@dartmouth.edu 


\section{Introduction}

Over the past fifteen years, developing countries have increased their participation in international financial markets and faced new challenges. In the aftermath of the $1997-$ 98 Asian financial crises, some observers have called on emerging markets to reduce short-term external debt relative to international reserve holdings in order to lower their vulnerability to crisis. Countries such as Korea, Taiwan and Chile have managed to build up large stockpiles of foreign-currency reserves in recent years. Does it follow that all developing countries would benefit from increasing their cushion of international reserves to signal they are safe borrowers? As the Lucas Critique suggests, this question cannot be answered without understanding the underlying factors that determine a country's choice of international reserve holdings.

We illustrate this point using a model where both efficiency and politicaleconomy considerations play roles in determining a country's optimal holdings of international reserves. In the absence of political-economy considerations, a country characterized by volatile output, inelastic demand for fiscal outlays, high tax collection costs and sovereign risk will want to accumulate both international reserves and external debt. External debt allows the country to smooth consumption when output is volatile. International reserves, if they are beyond the reach of creditors, allow the country to smooth consumption in the event of a default on the external debt that results in lost access to international capital markets. ${ }^{1}$

Domestic political uncertainty can modify the country's strategy. Suppose governments can alternate between a "tough" administration that enforces the planned fiscal allocation and a "soft" administration that behaves opportunistically, "looting" the combined assets of the treasury and central bank to channel additional resources towards narrow interest groups with high discount rates. If the present administration is "soft", it has little incentive to accumulate international reserves and carry them over to the future. It prefers to reduce international reserve holdings and increase international borrowing in order to maximize the current consumption of special interest groups. If the present

\footnotetext{
${ }^{1}$ International reserves thus provide insurance in case of default. For more on the insurance value of international reserves, see Van Wijnbergen (1990).
} 
administration is "tough", it may also be reluctant to accumulate international reserves if there is a high probability that the future administration will be "soft" and grab these reserves for favored insiders. Political instability, by taxing the effective return on reserves, can thus reduce desired current reserve holdings below the level supported by efficiency considerations. In the same way, political corruption acts as a tax on the return to holding reserves and reduces optimal holdings.

If a high external debt-to-reserve ratio is a symptom of political instability or corruption, then a policy recommendation to increase international reserve holdings in order to reduce that ratio may be welfare reducing. Indeed, increasing international reserves may increase the chance of financial crisis rather than reduce it.

The rest of the paper is organized as follows. In Section 2 we illustrate the confusion surrounding the appropriate level of reserves to hold by describing the current debate in Korea. In Section 3 we examine the empirical literature for the consensus view about determinants of reserve demand. We also present some new evidence suggesting reserves are held to insure against external shocks but may be reduced by political economy considerations. In Section 4 we present a model that shows how optimal international reserve holdings are sensitive to both efficiency and political economy concerns. Section 5 concludes.

\section{Korea's Debate About Optimal Reserve Holdings}

South Korea has the fifth largest holdings of international reserves in the world. Only Japan, China, Taiwan, and Hong Kong hold more. Reserves now account for about 20 percent of its GNP, compared with about 7 percent in 1996 and at the start of the 1990s. Reserves now cover more than 30 weeks of its imports, up from 11.8 weeks in 1996 and 12.9 weeks at the start of the 1990s. In January, 2002, South Korea's reserve holdings (excluding gold) were \$104 billion, a remarkable turnaround from the \$6 billion available at the end of 1997 in the midst of its financial crisis.

A debate is now under way in Korea over how much foreign-exchange reserves it should accumulate. According to the Korea Times, "one group contends that Korea's reserves are "excessive" and has proposed that amounts beyond the optimal level be invested abroad. But the Bank of Korea--currently in charge of managing the reserves-- 
and its sympathizers, argue that a small, open economy like Korea's must accumulate sufficient reserves to cope with unexpected occurrences like the currency crisis in 1997." (Korea Times, January 17, 2002)

Those who believe Korea's reserve holdings are excessive point to the fact that some reserves have been accumulated through government bond sales. Whereas reserves earn a current market rate of 2-3 percent, the government bonds carry an interest rate of 9 percent. They argue that Korea is paying unnecessarily high interest rates for reserves that are excessive to begin with. They favor the establishment of a governmentappointed body that would manage Korea's external assets and debts and invest reserves into profitable assets overseas.

Others dismiss the notion that Korea's reserves are excessive. They point out that it has been only four years since Korea was near bankruptcy, a number of Korean companies still face bankruptcy or low profitability, large amounts of foreign funds still move in and out of local stocks and other financial investments, and Korea cannot rule out the possibility of a future crisis. According to the Korea Times, the supporters of large reserve holdings believe "the costs linked to overcoming a currency crisis are astronomical while the gains to be made from the productive investment of the reserves will be quite small.” (Korea Times, January 17, 2002.)

Foreign policy uncertainties also appear to be a factor in Korea's decision to hold sizeable reserves. Many Korean economists maintain that Korea needs more than $\$ 500$ 1,000 billion in reserves for use if and when the two Koreas unite. (Korea Times, January 17, 2002). Should there be an escalation in inter-Korean tensions instead, they believe South Korea would also need a lot of reserves to buffer it from difficulties such as a panic by foreign investors. Thus some argue that Korea needs a very large stockpile of international reserves regardless of the future foreign policy outcome.

From the ongoing debate in Korea, it seems that the desire to protect the Korean economy from external shocks is the driving force behind the rapid accumulation of international reserves. Domestic political uncertainties have not been sufficiently important to keep reserves at a more modest level. 


\section{Empirical Evidence}

We wish to investigate whether political considerations play a significant role in determining international reserve holdings over and above the standard explanatory variables. Most previous empirical work on international reserve holdings relies on the buffer stock model to guide the specification. ${ }^{2}$ The buffer stock model says that central banks should choose a level of reserves to balance the macroeconomic adjustment costs incurred in the absence of reserves with the opportunity cost of holding reserves.

Reserve holdings turn out to be a stable function of just a few variables - the adjustment cost, the opportunity cost and reserve volatility. In practice, empirical work has generally excluded the opportunity cost measure because interest rate data on the alternative yield to reserves are unavailable for many developing countries and the measure is insignificant for developed ones.

A common strategy is to assume actual reserve holdings are proportional to optimal reserves up to an error that is uncorrelated with right-hand side variables. The estimating equation then becomes:

$$
\ln \left(\frac{R_{t}}{X_{t}}\right)=\alpha_{0}+\alpha_{1} \ln \left(S_{t}\right)+\alpha_{2} \ln \sigma_{t}+\alpha_{3} \ln \left(C_{t}\right)+\varepsilon_{t}
$$

The LHS of (1) is the log of actual reserve holdings (R), valued in U.S. dollars and expressed as a ratio of $\mathrm{X}$, where $\mathrm{X}$ is usually the U.S. GDP deflator. Since developing countries have minimal gold holdings, their international reserves are usually measured as "reserves minus gold" and include convertible foreign exchange, the unconditional drawing right with the IMF, and special drawing rights. The RHS of (1) shows observed reserves depending on a scaling variable (S), the volatility of international transactions $(\sigma)$ and adjustment costs $(\mathrm{C})$.

The scaling variable measures the size of international transactions and is generally represented by real GDP, real GDP per capita, or population size. It should

\footnotetext{
${ }^{2}$ For example, see Frenkel and Jovanovic (1981), Frenkel (1983), Edwards (1983), Lizondo and Mathieson (1987) and Flood and Marion (2001). An alternative view relies on the monetary approach to the balance of payments and relates changes in international reserves to changes in money demand. See Edwards (1984) and Elbadawi (1990). See International reserves thus provide insurance in case of default. For empirical evaluation on the insurance value of international reserves, see Ben-Bassat and Golllieb (1992).
} 
enter with a positive coefficient. The volatility of international receipts and payments is usually measured by the standard deviation of the trend-adjusted changes in reserves over some previous period. Since higher reserve volatility means that reserves hit their lower bound more frequently, the central bank should be willing to hold a larger stock of reserves in order to incur the cost of restocking less frequently. Volatility should enter with a positive coefficient. ${ }^{3}$

The marginal propensity to import was initially proposed as a proxy for adjustment costs. Early researchers noted that an external disequilibrium induced by a decline in export earning could be corrected by a decline in output. The smaller the marginal propensity to import, the greater the output decline needed to bring about the correction. The cost of output adjustment could be saved if the central bank financed the external deficit with its international reserves. Thus the cost of adjustment in the absence of reserves would be inversely related to the marginal propensity to import. (See Heller, 1966). In empirical work, the average propensity to import was used instead of the marginal propensity and its coefficient frequently turned out to be positive. The propensity to import was then reinterpreted to measure the economy's openness and vulnerability to external shocks. The positive coefficient suggested that the demand for reserves increases as the economy faces greater external vulnerability.

While equation (1) is the benchmark specification of reserve holdings based on a buffer stock model, some researchers have considered additional variables. For example, Flood and Marion, (2001) and Disyatat and Mathieson (2001) found that the volatility of the effective exchange rate is an important determinant. The choice of exchange-rate regime should affect international reserve holdings. Greater exchange-rate flexibility should reduce the demand for reserves since central banks no longer need a large reserve

\footnotetext{
${ }^{3}$ Alternative volatility measures have also been used. Edwards (1985) used the volatility of export receipts. Flood and Marion (2001) showed that the reserve volatility measure is contaminated because it combines the volatility of a standard reserve increment that is possibly distributed conditionally normally with large upward and downward jumps in reserves associated with reserve restocking or speculative attacks on reserve stocks, respectively. When upward jumps in reserves dominate, this volatility measure imparts a positive bias to the coefficient on reserve volatility. They chose to use a measure of fundamentals volatility.
} 
stockpile to maintain a peg or enhance the peg's credibility. The coefficient on exchange-rate volatility should therefore be negative.

Table 1 presents benchmark regressions, where the dependent variable is the log of reserves relative to either the U.S. price deflator, the country's public and publiclyguaranteed external debt, or the country's broad money supply (M2). ${ }^{4}$ It also reports results for regressions enhanced by adding political variables. The original panel data set consisted of 137 developing countries over the 1970-99 period, but missing data reduced the sample to 122 countries or less over the 1980-99 period, depending on the choice of explanatory variables. A data appendix describes variable definitions and sources.

Regression (1) is the benchmark regression when reserves are deflated by the US deflator and it confirms findings from earlier studies. The scale variables, population size and real GDP per capita, are positive and highly significant. Volatility, represented here by the volatility of real export receipts, and vulnerability to external shocks, measured by the country's openness, are also positive and highly significant. ${ }^{5}$ Greater exchange-rate variability significantly reduces reserve holdings. These five variables account for over 70 percent of the variation in observed reserve holdings without fixed effects. With fixed effects, the version reported in Table 1 , they account for 88 percent of the variation. The benchmark regression clearly illustrates that reserve holdings increase with volatility and the economy's growing vulnerability to external shocks.

Regressions (3) and (5) present benchmark regressions when reserves are scaled by external debt and broad money, respectively. Although the explanatory variables now explain less of the variation in reserve holdings, the results are qualitatively similar. More populous and higher per capita-income countries hold more reserves, greater volatility and vulnerability to exogenous shocks significantly increase reserve holdings,

\footnotetext{
${ }^{4}$ Benchmark regressions where reserves are expressed as a ratio of GDP or import months are not reported. The idea behind expressing the dependent variable as a ratio is that the authorities may choose to treat the ratio as the policy variable of interest.

${ }^{5}$ Terms-of-trade volatility may represent a more exogenous measure of uncertainty than the volatility of export receipts. By itself or interacted with openness, terms-of-trade volatility is not a significant determinant of reserve holdings when reserves are deflated by the U.S. price deflator or scaled by a country's external debt. However, terms-of-trade volatility interacted with openness has a positive and highly significant effect when reserves are scaled by the country's broad money, import months or GDP.
} 
and greater exchange-rate flexibility reduces reserve holdings, though not significantly in all cases.

Regressions (2), (4) and (6) add political variables to the benchmark regressions. We considered several political variables--the probability of a government leadership change by constitutional means, the probability of a government leadership change by unconstitutional means, and an index of political corruption. ${ }^{6}$ Since the probability of a leadership change by unconstitutional means was never a significant explanatory variable in any regression, we report regressions without it. ${ }^{7}$ The corruption index is based on a survey of foreign investors conducted by the International Country Risk Guide. A higher value indicates that high government officials are more likely to demand special payments and that illegal payments are expected to a greater degree throughout lower levels of government in connection with import and export licenses, exchange controls, tax assessment, police protection, or loans. Because there are fewer observations on the political variables (the data cover only 65 countries over the 1985-96 period), the sample size is reduced. ${ }^{8}$

Political factors do influence reserve holdings. When reserves are deflated by the U.S. price deflator (regression (2)) or expressed as a ratio of external debt (regression (4)), a greater probability of leadership change and greater political corruption both significantly reduce international reserve holdings. When reserves are expressed as a ratio of broad money (regression (6)), political corruption and political uncertainty are again negatively correlated with reserve holdings though only the corruption index is

\footnotetext{
${ }^{6}$ The probabilities of constitutional and unconstitutional leadership change are estimates from a multinomial logit that uses as explanatory variables the length of time in power, leader age, a political regime dummy, an election time dummy, regional dummies, and the number of previous leadership exits. The logit was conducted by David LaBlang (2000), who kindly agreed to share his results. The political corruption index is from the International Country Risk Guide and was kindly provided to us by Hamid Davoodi.

${ }^{7}$ The insignificance of this variable may be due, in part, to the fact that it was positively correlated with the corruption index and negatively correlated with real GDP per capita and openness.

${ }^{8}$ The benchmark regressions with the reduced sample size are substantially similar to the ones reported in Table 1.
} 
significant. We thus have some empirical support for the notion that political uncertainty or corruption effectively reduce the return to holding international reserves.

We next turn to a model that tries to rationalize these findings. The model departs from the buffer-stock approach and instead emphasizes the importance of international reserves and external debt in providing intertemporal consumption and distortion smoothing. The model incorporates features of developing economies and takes into account the possibility of opportunistic behavior.

\section{The Model}

We consider a two-period model of an emerging-market economy. The economy experiences productivity shocks that create a volatile tax base. It faces inelastic fiscal outlays and finds it costly to collect taxes. The economy can borrow internationally in the first period, but because there is some chance it will default in the second period, it faces a credit ceiling.

The central bank actively targets the stock of reserves. Even so, a variety of exchange-rate arrangements are possible, such as a fixed exchange rate or a managed float, because the balance sheets of the central bank and treasury are consolidated and the net taxes paid by consumers are determined as a residual. ${ }^{9}$

\section{Output}

Suppose that productivity shocks occur only in the second period. Then GDP in period $\mathrm{i}(\mathrm{i}=1,2)$ is

$$
\begin{aligned}
& Y_{1}=1 \\
& Y_{2}=1+\varepsilon
\end{aligned}
$$

where $\varepsilon$ is a productivity shock defined in the range $-\bar{\delta} \leq \varepsilon \leq \bar{\delta} ; 0 \leq \bar{\delta}$, with a corresponding density function $f(\varepsilon)$.

\footnotetext{
${ }^{9}$ This structure would also apply to the operation of export stabilization funds, such as Chile's cooper fund.
} 


\section{International Borrowing}

The emerging market can borrow in international capital markets. Suppose it borrows $B$ in period 1 at a contractual rate $r$, so it owes $(1+r) B$ in period 2 . If it faces a bad enough productivity shock in the second period, it defaults. Default is not without penalty, however. International creditors can confiscate some of the emerging market's export revenues or other resources equal to a share $\alpha$ of its output. We assume that the defaulting country's international reserve holdings are beyond the reach of creditors. ${ }^{10}$

In the second period, the country repays its international obligations if repayment is less costly than the default penalty. The country ends up transferring $\mathrm{S}_{2}$ real resources to international creditors in the second period, where:

$$
S_{2}=\operatorname{MIN}\left[(1+r) B ; \alpha Y_{2}\right], \quad 0<\alpha<1
$$

Let $\varepsilon^{*}$ be the value of the shock that causes the emerging market to switch from repayment to the default regime: ${ }^{11}$

$$
(1+r) B=\alpha\left(1+\varepsilon^{*}\right)
$$

Thus the future net resource transfer to international creditors will be:

$$
S_{2}=\left\{\begin{array}{lll}
(1+r) B & \text { if } & \varepsilon>\varepsilon^{*} \\
\alpha(1+\varepsilon) & \text { if } & \varepsilon \leq \varepsilon^{*}
\end{array}\right.
$$

\footnotetext{
${ }^{10}$ This is a realistic assumption. For example, on January 5, 2002, The Economist reported "[President Duhalde] confirmed that Argentina will formally default on its debt, an overdue admission of an inescapable reality. The government has not had access to international credit (except from the IMF) since July. It had already repatriated nearly all of its liquid foreign assets to avoid their seizure by creditors." (The Economist, p. 29)

${ }^{11}$ If the worst possible shock ( $\varepsilon=-\bar{\delta}$ ) still makes repayment preferable to default, then $\varepsilon^{*}$ is set equal to $-\bar{\delta}$.
} 
Suppose the risk-free interest rate is $r_{f}$. The interest rate attached to the country's acquired debt, $r$, is determined by the condition that the expected return on the debt is equal to the risk-free return:

$$
E\left[S_{2}\right]=\left(1+r_{f}\right) B
$$

From (4) we know that the expected return on the debt is the weighted average of the default penalty and full repayment, where the weights reflect the probability of each outcome:

$$
E\left[S_{2}\right]=\int_{-\bar{\delta}}^{\varepsilon^{*}} \alpha(1+\varepsilon) f(\varepsilon) d \varepsilon+\int_{\varepsilon^{*}}^{\bar{\delta}}(1+r) B f(\varepsilon) d \varepsilon=\left(1+r_{f}\right) B
$$

Differentiating (5'), we find that:

$$
\mathrm{d}[\mathrm{B}(1+\mathrm{r})] / \mathrm{dB}=(1+\mathrm{rf}) / \mathrm{Q}
$$

where $Q=\int_{\varepsilon^{*}}^{\bar{\delta}} f(\varepsilon) d \varepsilon$ is the probability of full repayment. If there is no chance of default, $Q=1$ and the country is charged the risk-free rate. But when there is some chance of default, the country is forced to pay a risk premium, since $0<Q<1$ implies $r>r_{f}$.

\section{The Fiscal Story}

The demand for public goods, such as health, pensions, and defense, is assumed to be completely inelastic and set at $\bar{G}$. Public goods expenditures are financed, in part, by tax revenues. Collecting taxes is assumed to be costly. Costs include direct collection and enforcement costs as well as indirect deadweight losses associated with the distortions induced by taxes. Like Barro (1979), we model these costs as a nonlinear share of output and let them depend positively on the tax rate. Thus a tax at rate $t$ yields net tax revenue of

$$
T(t)=Y[t-\Gamma(t)] ; \quad \Gamma^{\prime} \geq 0, \Gamma^{\prime \prime} \geq 0 .
$$


The term $\Gamma(t)$ measures the fraction of output lost because of inefficiencies in the tax collection system. $\Gamma(t)$ is assumed to increase at an increasing rate as the tax rate rises. It is convenient to specify the fiscal demand for net tax revenue as a share of GDP:

$$
\xi_{i}=\frac{T_{i}}{Y_{i}} ; \quad i=1,2
$$

Combining (7) and (8), we can express the tax rate as a function of the share of net tax revenue in GDP:

$$
t_{i}\left(\xi_{i}\right) ; \quad t^{\prime}>0
$$

For example, if the collection cost is quadratic in the tax rate, so that $\Gamma(t)=0.5 \lambda t^{2}$ where $\lambda$ measures the relative inefficiency of the tax system, then

$$
T(t)=Y\left[t-0.5 \lambda t^{2}\right]
$$

and

$$
t_{i}=\frac{1-\sqrt{1-2 \lambda \xi_{i}}}{\lambda}
$$

\section{Reserves}

The government can acquire international reserves in the first period, let them earn the risk-free rate, and spend them in the second period. One way of acquiring reserves is through sovereign borrowing. Even if reserves are acquired as the counterpart of private-sector borrowing, full sterilization by the central bank implies an ultimate swap of sovereign debt for reserves. Another way of accumulating reserves is through taxation. Higher taxes depress domestic absorption and generate a bigger current-account surplus in the first period. In the second period, reserves may be spent to finance repayment of the international debt and government expenditures. In a two-period model, there is no need to hold reserves beyond the second period. Thus the terminal demand for reserves is zero.

The government faces the following budget constraints: 


$$
\begin{aligned}
& T_{1}=\bar{G}+R-B ; \\
& T_{2}=\bar{G}+S_{2}-\left(1+r_{f}\right) R
\end{aligned}
$$

In the first period, spending on public goods and reserve accumulation must be financed by taxes and foreign borrowing. In the second period, spending on public goods and debt repayments must be financed by taxes and available reserves.

\section{Optimization}

We now wish to evaluate the optimal foreign borrowing and demand for international reserves by a country with a costly tax collection system and some chance of defaulting. Subject to the government budget constraints in (12), the policy maker chooses the foreign debt and international reserves to acquire in the first period in order to maximize the intertemporal utility of consumers:

$$
\operatorname{Max} V=\mathrm{u}\left(\mathrm{C}_{1}\right)+\frac{1}{(1+\rho)} \int_{-\bar{\delta}}^{\bar{\delta}} u\left(C_{2}\right) f(\varepsilon) d \varepsilon
$$

In (13), consumer preferences are characterized by a conventional time-separable utility, where $\rho$ is the discount rate. Consumer spending in each period is merely output net of taxes, where taxes include collection costs:

$$
C_{i}=Y_{i}\left[1-\xi_{i}-\Gamma\left(t\left(\xi_{i}\right)\right)\right] ; \quad i=1,2^{12}
$$

Given the definition of output in (1), consumer spending in period 1 is $C_{1}=\left[1-\xi_{1}-\Gamma\left(t\left(\xi_{1}\right)\right)\right]$ while consumer spending in period 2 is $C_{2}=\left[1-\xi_{2}-\Gamma\left(t\left(\xi_{2}\right)\right)\right](1+\varepsilon)$. For future reference, it is useful to note that the marginal cost of public funds, $-\partial C_{i} / \partial T_{i}$, can be inferred from (14) to be:

\footnotetext{
${ }^{12}$ Applying (7) and the definition of $\xi$, we know $\xi Y_{i}=T_{i}=\left[t_{i}-\Gamma\right] Y_{i}$. Thus $t_{i}=\xi_{i}+\Gamma_{i}$, and $C_{i}=Y_{i}\left(1-t_{i}\right)=Y_{i}\left(1-\xi_{i}-\Gamma_{i}\right)$.
} 


$$
1+\Gamma^{\prime}(\xi) \quad \text { where } \Gamma^{\prime}(\xi)=\frac{d \Gamma}{d t} \frac{d t}{d \xi} \cdot 13
$$

while from (8) and (12) we know that:

$$
\xi_{1}=\frac{T_{1}}{Y_{1}}=\bar{G}+R-B ; \quad \xi_{2}=\frac{T_{2}}{Y_{2}}=\frac{\bar{G}+S_{2}-\left(1+r_{f}\right) R}{1+\varepsilon}
$$

and $S_{2}$ is given by (5').

The first-order condition that determines optimal borrowing is

$$
u^{\prime}\left(C_{1}\right)\left\{1+\Gamma^{\prime}\left(\xi_{1}\right)\right\}-\int_{\varepsilon^{*}}^{\bar{\delta}}\left\{\frac{1}{1+\rho} u^{\prime}\left(C_{2}\right)\left\{1+\Gamma^{\prime}\left(\xi_{2}\right)\right\}\right\} f(\varepsilon) d \varepsilon \frac{1+r_{f}}{Q}=0,
$$

which can be rewritten as

$$
\int_{\varepsilon^{*}}^{\bar{\delta}}\left\{u^{\prime}\left(C_{1}\right)\left\{1+\Gamma^{\prime}\left(\xi_{1}\right)\right\}-\left(\frac{1+r_{f}}{1+\rho}\right) u^{\prime}\left(C_{2}\right)\left\{1+\Gamma^{\prime}\left(\xi_{2}\right)\right\}\right\} f(\varepsilon) d \varepsilon=0
$$

The first-order condition that determines optimal first-period reserve holdings is:

$$
\int_{-\bar{\delta}}^{\varepsilon^{*}}\left\{u^{\prime}\left(c_{1}\right)\left\{1+\Gamma^{\prime}\left(\xi_{1}\right)\right\}-\left(\frac{1+r_{f}}{1+\rho}\right) u^{\prime}\left(c_{2}\right)\left\{1+\Gamma^{\prime}\left(\xi_{2}\right)\right\}\right\} f(\varepsilon) d \varepsilon=0
$$

If the country fully repays its foreign debts $(\mathrm{Q}=1)$, optimal borrowing equates the expected present value of the marginal cost of public funds in the two periods. It therefore provides expected smoothing of the tax burden over time. Put differently, the policy maker borrows in the first period up to the point where the gain in the consumer's

\footnotetext{
${ }^{13}$ This result follows from the observation that $d C_{i} / d T_{i}=-Y_{i}\left[1+\Gamma^{\prime}\right] d \xi_{i} / d T_{i}$ and $d \xi_{i} / d T_{i}=1 / Y_{i}$. The marginal cost of public funds can also be written as $1+\Gamma^{\prime}(\xi)=1 /[1-d \Gamma / d t]$. Since $t_{i}=\xi_{i}+\Gamma_{i}$, we know that $d t_{i} / d \xi_{i}=1+\Gamma^{\prime}\left(\xi_{i}\right)=1+\left(d \Gamma_{i} / d t_{i}\right)\left(d t_{i} / d \xi_{i}\right)$. Rearranging terms, we find that $d t_{i} / d \xi_{i}=1 /\left[1-d \Gamma_{i} / d t_{i}\right)=1+\Gamma^{\prime}(\xi)$.
} 
first-period marginal utility is equal to the expected loss of second-period marginal utility that comes from raising future taxes to repay the debt.

If a bad enough shock reduces future output so much that the country defaults (i.e., if $\mathrm{Q}<1$ ), then the country pays the default penalty. In the absence of international reserve holdings to finance second-period public expenditures, the country also needs to raise taxes. Condition (17) implies that external borrowing alone is insufficient for achieving intertemporal smoothing of the tax burden in all states of nature.

Figure 1 illustrates the first-order condition that must be met in order to maximize the intertemporal utility of the consumer. It plots the present value of the expected second-period marginal cost of public funds, $\frac{1+r_{f}}{1+\rho} u^{\prime}\left(C_{2}\right)\left[1+\Gamma^{\prime}\left(\xi_{2}\right)\right]$, as a function of the second-period productivity shock. The curve is downward sloping. The reason is twofold. First, more positive output shocks generate higher output and lower the marginal cost of obtaining public funds. Second, higher levels of consumption lead to diminishing marginal utility, lowering the marginal cost of taxes. Observe that an increase in borrowing shifts up the curve. It raises the marginal cost of funds in the second period, expanding the range of shocks where default occurs, and it reduces the marginal cost of funds in the first period. Optimal borrowing equates the expected second-period marginal cost of public funds evaluated over the distribution of shocks that induce full repayment [point $\mathrm{N}$ in Figure 1] to the cost of public funds in the first period, illustrated by the horizontal broken line.

Figure 2 characterizes optimal borrowing. Specifically, schedule $M C_{1}$ is the first-period marginal cost of raising public funds, $u^{\prime}\left(C_{1}\right)\left\{1+\Gamma^{\prime}\left(\xi_{1}\right)\right\}$. Curve $\overline{M C}_{2}$ is the discounted second-period marginal cost of public funds, evaluated in the range of full repayment, $\int_{\varepsilon^{*}}^{\bar{\delta}}\left\{\frac{1}{1+\rho} u^{\prime}\left(C_{2}\right)\left\{1+\Gamma^{\prime}\left(\xi_{2}\right)\right\}\right\} f(\varepsilon) d \varepsilon \frac{1+r_{f}}{Q} \cdot{ }^{14}$ Optimal borrowing is characterized by the intersection of both curves.

\footnotetext{
${ }^{14}$ While curve $M C_{1}$ is always sloping upward, curve $\overline{M C}_{2}$ may be downward sloping, as higher $\mathrm{B}$ reduces the range of full repayment. The second-order condition for
} 
In the absence of sovereign risk, $Q=1$ and the first-order condition for optimal borrowing simplifies to:

$$
\left(17^{\prime \prime}\right) u^{\prime}\left(C_{1}\right)\left\{1+\Gamma^{\prime}\left(\xi_{1}\right)\right\}=\left(\frac{1+r_{f}}{1+\rho}\right) E\left[u^{\prime}\left(C_{2}\right)\left\{1+\Gamma^{\prime}\left(\xi_{2}\right)\right\}\right]
$$

Optimal borrowing equates the expected cost of public funds across time. The left-hand side of (17") captures the utility gain in the first period associated with funding one unit of fiscal expenditure by borrowing instead of taxes. The right-hand side measures the expected utility loss of raising future taxes in order to repay the first-period borrowing. ${ }^{15}$ If the consumer is risk neutral and if $r_{f}=\rho$, optimal borrowing allows for intertemporal smoothing of the tax burden, as in Barro (1979). In these circumstances the marginal cost of raising one unit of net tax revenue in the current period equals the expected present value cost of raising one unit of net taxes in the future.

To understand the role of international reserves, we evaluate the impact of the first unit of reserves on consumer utility. Differentiating (18) with respect to reserves, we find that

$$
\frac{\partial V}{\partial R}=-u^{\prime}\left(c_{1}\right)\left\{1+\Gamma^{\prime}\left(\xi_{1}\right)\right\}+\frac{1+r_{f}}{1+\rho} \int_{-\bar{\delta}}^{\bar{\delta}} u^{\prime}\left(c_{2}\right)\left\{1+\Gamma^{\prime}\left(\xi_{2}\right)\right\} f(\varepsilon) d \varepsilon
$$

Evaluating (19) around an initial equilibrium where $R=0$ and borrowing is optimal, we find that:

maximization, $\frac{\partial^{2} V}{\partial B^{2}}<0$, implies that the slope of $\overline{M C}_{2}$ exceeds the slope of $M C_{1}$ (i.e., $\left.\frac{\partial\left[\overline{M C}_{2}-M C_{1}\right]}{\partial B}>0\right)$.

${ }^{15}$ Note that raising one unit of net taxes increases the gross tax bill by $1+\Gamma^{\prime}\left(\xi_{1}\right)$. Borrowing one unit increases first-period utility by the product of the gross tax saving and the marginal utility. 
(20) $\frac{\partial V}{\partial R} \mid R=0$, optimal $B=\int_{-\bar{\delta}}^{\varepsilon^{*}}\left[\left(\frac{1+r_{f}}{1+\rho}\right)\left[1+\Gamma^{\prime}\left(\xi_{2}\right)\right] u^{\prime}\left(c_{2}\right)-\left[1+\Gamma^{\prime}\left(\xi_{1}\right)\right] u^{\prime}\left(c_{1}\right)\right] f(\varepsilon) d \varepsilon>0$

Acquiring the first unit of reserves increases utility since it helps cushion the fall in second-period consumption should a bad shock trigger default. The larger the difference between first-period and second-period marginal utility when there is a default and no reserve cushion, the bigger the gain in utility from having international reserves to draw on when there is a default.

International reserves thus provide insurance. They help the economy smooth consumption intertemporally in the event of default. The combination of optimal external borrowing and optimal reserve accumulation permits expected consumption smoothing between period one and states of nature in period two when there is either full repayment of the foreign debt or default.

The result in (20) can be illustrated in Figure 1. Recall that point $N$ represents the expected second-period marginal cost of public funds evaluated over the distribution of shocks that induce full repayment. Point D corresponds to the expected second-period marginal cost of public funds evaluated over the distribution of shocks that cause default. The gain in utility from acquiring the first unit of reserves is proportional to the vertical gap between points $\mathrm{D}$ and $\mathrm{N}$.

A country with international reserves can transfer public funds from period one, where their marginal cost is low, to states of nature where bad shocks reduce output and trigger default. These are also the states of nature where the marginal cost of public funds is high. Hence, the benefit of holding international reserves is greatest when the country has an inefficient tax system and the probability of default is high. ${ }^{16}$

\footnotetext{
${ }^{16}$ Figure 1 corresponds only to the equilibrium where $\mathrm{R}=0$. Increasing $\mathrm{R}$ would impact both the location and the shape of the curve tracing the marginal cost of public funds. For example, when $\bar{G}<R\left(1+r_{f}\right)$, the marginal cost curve is upward sloping over the range of shocks that lead to default.
} 
The first-order condition that determines optimal borrowing can also be used to show that: ${ }^{17}$

$$
\text { (21) }\left.\frac{\partial B}{\partial R}\right|_{\text {optimal B }}>0
$$

At the margin, acquiring international reserves increases the optimal amount of foreign borrowing. Obtaining reserves in period one not only makes more resources available in period two, but these resources are insulated from second period's productivity shock. The net effect of acquiring reserves is to reduce the need for additional tax revenue in the future when there is a default. Having reserves thus reduces the expected cost of obtaining public funds in the future and increases the cost of acquiring public funds in the present. The change in the cost profile encourages more borrowing in the first period.

In terms of Figure 2, the effect of reserve accumulation is to shift curve $M \mathrm{C}_{1}$ upwards, and to shift curve $\overline{M C}_{2}$ downward, to the dotted curves. Both effects increase optimal borrowing. ${ }^{18}$ This process will continue until the optimal level of reserves is reached or until B reaches the credit constraint, whichever occurs first.

Figure 3 illustrates how international reserve holdings increase optimal borrowing at the margin. The figure simulates $\mathrm{B}$ as a function of $\mathrm{R}$ for the case where agents are risk neutral and the productivity shock follows a uniform distribution. ${ }^{19}$ As long as the

${ }^{17}$ Applying the first order condition determining optimal borrowing it also follows that $\operatorname{sgn}\left[\frac{\partial B}{\partial R \mid \text { optimal } B}\right]=\operatorname{sgn}\left[\frac{\partial^{2} V}{\partial R \partial B} \mid\right.$ optimal $\left.B\right]=$ $\left.\operatorname{sgn}\left[\int_{\varepsilon^{*}}^{\bar{\delta}}\left\{\frac{-u^{\prime \prime}\left(c_{1}\right)\left[1+\Gamma^{\prime}\left(\xi_{1}\right)\right]^{2}+u^{\prime}\left(c_{1}\right) \Gamma^{\prime \prime}\left(\xi_{1}\right)+}{1+\rho}\left[-u^{\prime \prime}\left(c_{2}\right)\left[1+\Gamma^{\prime}\left(\xi_{2}\right)\right]^{2}+u^{\prime}\left(c_{2}\right) \Gamma^{\prime \prime}\left(\xi_{2}\right)\right]\right\}\right\} f(\varepsilon) d \varepsilon\right]>0$

${ }^{18}$ Figure 2 is plotted for the case where $\overline{M C}_{2}$ is upward sloping. Higher $\mathrm{R}$ will increase $\mathrm{B}$ even if $\overline{M C}_{2}$ is downward sloping, as its slope exceeds that of $M \mathrm{C}_{1}$.

19 This simulation plots values of $\mathrm{B}$ that solve

$$
\int_{\varepsilon^{*}}^{\bar{\delta}}\left\{\frac{1}{\sqrt{1-2 \lambda[\bar{G}+R-B]}}-\frac{1+r_{f}}{1+\rho} \frac{1}{\sqrt{1-2 \lambda\left[\bar{G}-R\left(1+r_{f}\right)+(1+r) B\right]}}\right\} f(\varepsilon) d \varepsilon=0
$$


borrowing constraint is not reached, the process of acquiring reserves will continue as long as $\left.\frac{\partial V}{\partial R}\right|_{\text {optimal } B}>0$. The optimal R corresponds to the point where the external borrowing constraint is reached, at $\mathrm{B}=\alpha=0.1{ }^{20}$ The net effect of increasing reserves is to increase the net external debt, $\mathrm{B}-\mathrm{R}$, to about 0.065 .

The above discussion suggests that there are strong efficiency reasons for holding international reserves. Apart from any need to hold reserves for exchange-rate management, reserves help a country smooth consumption when there is a positive probability of default and a binding international credit ceiling. We now consider how political economy factors may undermine efficiency reasons for holding reserves and result in reduced reserve holdings.

\section{A Political Economy Story}

We now consider an economy where interest groups compete for additional fiscal resources to support their specific agendas. Realized fiscal expenditure is the outcome of this competition. Interest groups may be represented by cabinet ministers or, in a federal system, by the governors of various states or provinces. We retain our earlier assumption that consumer utility can be characterized by (13). Such will be the case if interest groups pursue narrow agendas and their marginal spending does not directly impact the representative consumer's welfare. The tax consequences of successful lobbying efforts will have the usual adverse effect on the consumer's utility, however.

The Treasury Minister (TM) is assumed to determine the ultimate fiscal allocation. We assume two types of Treasury Ministers - soft and tough. A soft one accommodates all the fiscal demands of the various interest groups up to the limit

for a given $\mathrm{R}$, where the interest rate $\mathrm{r}$ is determined by ( $\left.5^{\prime}\right)$.

20 Note that the credit ceiling is reached where $Q=0$. Hence $B\left(1+r_{f}\right)=\int_{-\bar{\delta}}^{\bar{\delta}} \alpha(1+\varepsilon) f(\varepsilon) d \varepsilon=\alpha$. The value of $\mathrm{R}$ is inferred from the condition $\int_{-\bar{\delta}}^{\bar{\delta}}\left\{\frac{1}{\sqrt{1-2 \lambda[\bar{G}+R-\alpha]}}-\frac{1+r_{f}}{1+\rho} \frac{1}{\sqrt{1-2 \lambda\left[\bar{G}-R\left(1+r_{f}\right)+\left(1+r_{f}\right) \alpha\right]}}\right\} f(\varepsilon) d \varepsilon=0$. 
imposed by the contemporaneous budget constraint. A tough one forces the interest groups to adhere to the planned allocation, $\bar{G}$. There is uncertainty in period one about the type of Treasury Minister that will serve in period two. With probability $\phi$ the future Treasury Minister will be tough.

The sequence of events is as follows. In period one, the interest groups determine their desired second-period demand for fiscal resources. At the beginning of the second period, the productivity shock and the Treasury Minister's type are revealed. A soft TM in the second period will divide the maximum available fiscal resources, net of foreign debt repayments, among all the interest groups. In that case, aggregate fiscal expenditure and consumption in the second period will be:

$$
\begin{aligned}
& G_{\text {|Soft 2nd period }}=(1+\varepsilon)\left\{t_{m}-\Gamma\left(t_{m}\right)\right\}+R\left(1+r_{f}\right)-S_{2} ; \\
& C_{\text {|Soft 2nd period }}=(1+\varepsilon)\left\{1-t_{m}\right\}
\end{aligned}
$$

where $t_{m}$ is the tax rate that maximizes net tax revenue and is obtained by solving $\operatorname{MAX}\{t-\Gamma(t)\}$. For example, with quadratic collection costs,

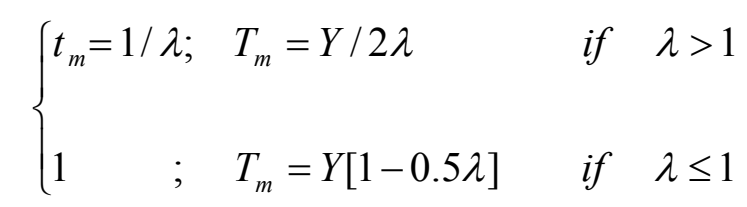

where $T_{m}$ is the maximum net tax revenue attainable [i.e. $T_{m}=Y\left\{t_{m}-\Gamma\left(t_{m}\right)\right\}$ ].

If the TM is also soft in the first period, fiscal expenditure in period one will equal the maximum contemporaneous resources available. This outcome is the result of assuming interest groups have high discount rates and prefer maximizing first-period fiscal expenditure. A soft TM will therefore have no incentive to acquire international reserves and carry them over to the future period. Moreover, a soft TM will borrow in the first period up to the external credit ceiling, $\alpha /\left(1+r_{f}\right)$. Consequently, first-period fiscal expenditure and consumption observed with a soft TM are: 


$$
\begin{aligned}
& G_{\mid \text {Soft 1st period }}=1\left\{t_{m}-\Gamma\left(t_{m}\right)\right\}+\frac{\alpha}{1+r_{f}} ; \\
& C_{\mid \text {Soft 1st period }}=1\left\{1-t_{m}\right\}
\end{aligned}
$$

The public finance problem solved by the soft TM has a trivial solution: maximize the fiscal outlay in period one. To do so, the first-period TM sets the tax rate at the peak of the tax Laffer Curve, borrows up to the external credit ceiling, and accumulates no international reserves.

We turn now to the more complex case, where a tough TM in the first period must determine the amount of international reserves and foreign debt to acquire in order to maximize the expected utility of the representative agent. The tough TM does not know the second-period productivity shock or TM-type, only the distribution of the productivity shock and the probability of having a particular TM-type. The tough TM's objective is to maximize:

$$
\begin{aligned}
& V_{\mid \text {Tough 1st period }}=u\left[1-\xi_{1}-\Gamma\left(t\left(\xi_{1}\right)\right)\right]+ \\
& \frac{\phi}{1+\rho} \int_{-\bar{\delta}}^{\bar{\delta}} u\left[(1+\varepsilon)\left[1-\frac{S_{2}+\bar{G}-R\left(1+r_{f}\right)}{1+\varepsilon}-\Gamma\left(t\left(\frac{S_{2}+\bar{G}-R\left(1+r_{f}\right)}{1+\varepsilon}\right)\right]\right] f(\varepsilon) d \varepsilon\right. \\
& \frac{1-\phi}{1+\rho} \int_{-\bar{\delta}}^{\bar{\delta}} u\left[(1+\varepsilon)\left(1-t_{m}\right)\right] f(\varepsilon) d \varepsilon
\end{aligned}
$$

Inspection of (25) reveals that whatever choice the tough TM makes about first-period external debt and reserve holdings, it will not affect expected future utility should the soft TM be in office next period (the last term in (25)). Hence, maximizing (25) delivers firstorder conditions identical to those derived in the previous section, except that now second-period utility is discounted at rate $\frac{\phi}{1+\rho}$ instead of $\frac{1}{1+\rho}$. The tough TM in the initial period must satisfy the first-order conditions:

$$
\int_{\varepsilon^{*}}^{\bar{\delta}}\left\{u^{\prime}\left(c_{1}\right)\left\{1+\Gamma^{\prime}\left(\xi_{1}\right)\right\}-\phi \frac{1+r_{f}}{1+\rho} u^{\prime}\left(c_{2}\right)\left\{1+\Gamma^{\prime}\left(\xi_{2}\right)\right\}\right\} f(\varepsilon) d \varepsilon=0
$$




$$
-\int_{-\bar{\delta}}^{\bar{\delta}}\left\{u^{\prime}\left(c_{1}\right)\left\{1+\Gamma^{\prime}\left(\xi_{1}\right)\right\}-\phi\left(\frac{1+r_{f}}{1+\rho}\right) u^{\prime}\left(c_{2}\right)\left\{1+\Gamma^{\prime}\left(\xi_{2}\right)\right\}\right\} f(\varepsilon) d \varepsilon=0 .
$$

Inspection of (26) and (27) reveals that political uncertainty about whether the future Treasury Minister will be soft or tough induces today's tough TM to reduce the shadow real interest rate on borrowing and international reserves from $1+r_{f}$ to $\phi\left(1+r_{f}\right)$. If the country operates in the range where saving increases with the real interest rate and borrowing depends negatively on its expected cost, the higher probability of a soft future governor will lead to higher borrowing and lower international reserves accumulation in period 1. In the Appendix we provide the precise conditions needed to obtain this outcome.

The rationale for holding reserves is to increase tomorrow's buying power. The greater the probability of having a soft TM in the future ( a small $\phi$ ), the smaller the weight attached to the benefit of having high reserves in the future to increase purchasing power. With probability $(1-\phi)$ the reserves will be appropriated —or looted-- by a soft TM who will distribute them to various interest groups via higher fiscal expenditure.

Similarly, the greater the probability of having a soft TM in the future, the more borrowing a tough TM will undertake today. Greater borrowing today increases future debt service and reduces the resources left for the soft TM to distribute.

It is interesting to note that the greater the chance of having a soft TM in the future, the more likely today's tough TM will mimic the behavior of a soft TM in the first period, reducing optimal reserve holdings and increasing optimal borrowing. Of course, the motivation is different. A tough TM in the first period chooses fewer reserves and more borrowing in the first period to reduce expected future looting. The absence of reserve holdings and high borrowing adopted by the soft TM is the outcome of present looting. Nevertheless, we can conclude that a greater chance of opportunistic behavior by future policy makers reduces the demand for international reserves and increases external borrowing. By the same analysis, a greater degree of political corruption directly increases the likelihood of looting and leads to reduced reserve holdings. 


\section{Conclusion}

One general point is worth emphasizing. Political instability and political corruption reduce the optimal size of buffer stocks. This point is illustrated in the context of the demand for international reserves, but it is applicable to other stabilization fund schemes as well. Our model described an economy where a higher chance of future looting by an opportunistic policy maker reduces the current demand for international reserves. A similar point has been made in the context of a polarized political system, where political parties differ in their spending priorities. A higher probability of losing power to the opposing party reduces the saving of the present administration [see Alesina and Tabellini (1990) and Cukierman, Edwards and Tabellini (1992)].

Our empirical work suggests that greater attention should be given to the role of political-economy factors in explaining the demand for reserves and the functioning of buffer stocks. We found that the probability of leadership change and political corruption influenced the demand for reserves even after controlling for standard determinants and fixed effects. Due to data limitations, we were unable to investigate the effects of external threats and internal political polarization on the demand for international reserves. ${ }^{21}$ Theoretical considerations suggest that external threats should increase reserve holdings whereas internal political polarization should decrease them.

Another issue deserving further attention is the impact of access to international borrowing on the demand for reserves. Indeed, our modeling suggests that international borrowing and international reserve accumulation are the simultaneous outcome of optimizing decisions. Accounting for international borrowing may require information not only about the sovereign risk premium but also about the supply-elasticity of credit facing the economy. Both factors will affect the cost of relying on foreign borrowing to smooth adjustment in the face of future adverse shocks. Addressing these issues is left for future work.

\footnotetext{
${ }^{21}$ Important data sets of political variables, such as Taylor and Jodice (1983) and Banks $(1985,1994)$ have not been extended through the 1990s. Political measures of external foreign policy threats are available only by decade.
} 


\section{References}

Aizenman, Joshua and Michael Gavin and Ricardo Hausmann (2000), “Optimal Tax and Debt Policy with Endogenously Imperfect Creditworthiness," Journal of International Trade and Economic Development, 367-395.

Alesina, Alberto and Guido Tabellini (1990). A Positive Theory of Fiscal Deficits and Government Debt, The Review of Economic Studies, Vol. 57, No. 3. (July), pp. 403-414.

Banks, Arthur (1994). Political Handbook of the World, New York: McGraw-Hill.

Barro, Robert. (1979). “On the Determination of the Public Debt,” Journal of Political Economy 87, No. 5 (October), 940-971.

Ben-Bassat Avraham and Daniel Gottlieb (1992). "Optimal international reserves and sovereign risk," Journal of International Economics, pp. 345-362.

Cukierman, Alex, Sebastian Edwards, Guido Tabellini (1992). "Seigniorage and Political Instability, The American Economic Review, Vol. 82, No. 3. (June), pp. 537-555.

Disyatat, Piti and Donald Mathieson. (2001). "Currency Crises and the Demand for Foreign Reserves," Working Paper, IMF Research Department.

Eaton, Jonathan and Mark Gersovitz (1980). "LDC Participation in International Financial Markets: Debt and Reserves," Journal of Development Economics 7, 321.

Edwards, Sebastian (1983). “The Demand for International Reserves and Exchange Rate Adjustments: The Case of LDCs, 1964-1972,” Economica 50 (August), 269-280. (1984). "The Demand for International Reserves and Monetary Equilibrium: Some Evidence from LDCs", Review of Economics and Statistics 66 (August). 495-500.

Elbadawi, Ibrahim. (1990). "The Sudan Demand for International Reserves: A Case of a Labour-Exporting Country," Economica 57 (February), 73-89.

Flood, Robert and Nancy Marion (2001). "Holding International Reserves in an Era of High Capital Mobility," in Susan M. Collins and Dani Rodrik, Editors, Brookings Trade Forum 2001, Washington, D.C. : Brookings Institution Press, 2002.

“Foreign Exchange Reserves and Unification Cost," Korea Times, January 17, 2002. 
Frenkel, Jacob and Boyan Jovanovic (1981). "Optimal International Reserves: A Stochastic Framework,” Economic Journal 91 (June), 507-514.

Frenkel, Jacob (1983). "International Liquidity and Monetary Control,” in George m. von Furstenberg (editor) International Money and Credit: The Policy Roles, Washington: International Monetary Fund, 65-109.

Heller, Robert (1966). “Optimal International Reserves,” Economic Journal 76 (June), 296-311.

LaBlang, David A. (2000). "Political Uncertainty and Speculative Attacks," working paper, Department of Political Science, University of Colorado, Boulder.

Lizondo, Jose and Don Mathieson (1987). "The Stability of the Demand for International Reserves," Journal of International Money and Finance 6, 251-282.

Taylor, Charles and David Jodice (1983). World Handbook of Social and Political Indicators, New Haven: Yale University Press.

Tanzi, Vito and Hamid Davoodi (1997). "Corruption, Public Investment, and Growth," IMF Working Paper WP/97/139, October.

Van Wijnbergen, Sweder (1990). "Cash/Debt Buy-Backs and the Insurance Value of Reserves," Journal of International Economics 29 (August), 123-131. 


\section{Appendix}

A higher probability of a soft future administration leads to higher borrowing and lower international reserves accumulation in period 1:

(A1) $\frac{d B}{d \phi}<0 ; \quad \frac{d R}{d \phi}>0$

We show this will be the case in an internal equilibrium where the complementarily between reserves and borrowing is not too great.

Note that the first-order conditions for determining the behavior of the tough policy maker in the first period, (26) and (27), are:

(A2)

$$
\begin{aligned}
& \frac{\partial V_{\mid \text {Tough 1 st period }}}{\partial B}=0 \\
& \frac{\partial V_{\mid \text {Tough 1 st period }}}{\partial R}=0
\end{aligned}
$$

Hence,

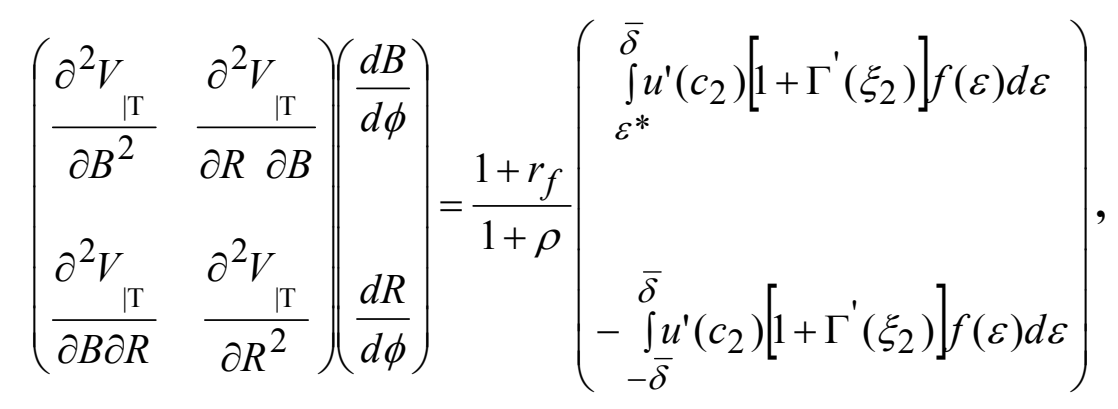

where $V_{\mid \mathrm{T}}$ is a shortened notation for $V_{\mid \text {Tough } 1 \text { st period }}$.

Thus, 


$$
\begin{aligned}
& \left.\frac{d B}{d \phi}=\frac{1+r_{f}}{1+\rho}\left[\int_{\varepsilon^{*}}^{\bar{\delta}} u^{\prime}\left(c_{2}\right)\left[1+\Gamma^{\prime}\left(\xi_{2}\right)\right] f(\varepsilon) d \varepsilon \frac{\partial^{2} V}{\partial R^{2}}+\int_{-\bar{\delta}}^{\bar{\delta}} u^{\prime}\left(c_{2}\right)\left[1+\Gamma^{\prime}\left(\xi_{2}\right)\right] f(\varepsilon) d \varepsilon \frac{\partial^{2} V}{\partial R}\right] \operatorname{TT}\right] / D \\
& \frac{d R}{d \phi}=\frac{1+r_{f}}{1+\rho}\left[-\int_{-\bar{\delta}}^{\bar{\delta}} u^{\prime}\left(c_{2}\right)\left[1+\Gamma^{\prime}\left(\xi_{2}\right)\right] f(\varepsilon) d \varepsilon \frac{\partial^{2} V}{\partial B^{2}}-\int_{\varepsilon^{*}}^{\bar{\delta}} u^{\prime}\left(c_{2}\right)\left[1+\Gamma^{\prime}\left(\xi_{2}\right)\right] f(\varepsilon) d \varepsilon \frac{\partial^{2} V}{\partial B \partial R}\right] / D
\end{aligned}
$$

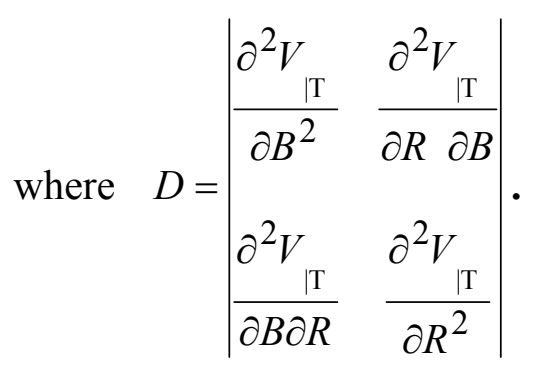

Applying (25) we infer that $\frac{\partial^{2} V}{\partial B^{2}}<0 ; \quad \frac{\partial^{2} V_{\mid \mathrm{T}}}{\partial R^{2}}<0 ; \quad \frac{\partial^{2} V}{\partial B \partial R}>0$. The second order

condition for internal optimization implies that $\mathrm{D}$ is positive. This will be the case if the complementary between B and R (as measured by $\frac{\partial^{2} V}{\partial B \partial R}$ ) is smaller that the geometric average of the direct effects of $\mathrm{B}$ and R (i.e., if $\sqrt{\frac{\partial^{2} V}{\partial B^{2}} \frac{\partial^{2} V}{\partial R^{2}}}>\frac{\partial^{2} V}{\partial B \partial R}$ ). Inspection of (A4) reveals that a sufficient condition to sign the impact of changing the probability of a future soft policy maker is that the complementarity between B and R is low enough. In these circumstances, ${ }^{22}$

$$
\frac{d B}{d \phi}<0 ; \quad \frac{d R}{d \phi}>0
$$

\footnotetext{
${ }^{22}$ It is easy to confirm that for a given $\mathrm{B}$, a higher return on $\mathrm{R}$ would increase the optimal demand for R. Similarly, for a given R, higher expected borrowing costs would reduce $\mathrm{B}$. Due to the complementarity between $\mathrm{B}$ and $\mathrm{R}$, there are secondary effects: the increase in $\mathrm{R}$ triggered by higher returns will increase $\mathrm{B}$, whereas the drop in $\mathrm{B}$ induced by the higher cost of borrowing will reduce $\mathrm{R}$. The direct effects will dominate the secondary effects only if the complementarity between $\mathrm{B}$ and $\mathrm{R}$ is not too great.
} 


\section{TABLE 1: Determinants of Reserve Holdings}
(1)
(2)
(3)
(4)
(5)
(6)

\begin{tabular}{|c|c|c|c|c|c|c|}
\hline obs & 1954 & 915 & 1937 & 901 & 1948 & 914 \\
\hline countries & 122 & 65 & 122 & 65 & 122 & 65 \\
\hline dep var & $\ln (\mathrm{R} / \mathrm{P})$ & $\ln (\mathrm{R} / \mathrm{P})$ & $\ln (\mathrm{R} / \mathrm{Debt})$ & $\ln (\mathrm{R} / \mathrm{Debt})$ & $\ln (\mathrm{R} / \mathrm{M} 2)$ & $\ln (\mathrm{R} / \mathrm{M} 2)$ \\
\hline lpop & $\begin{array}{l}2.1762 * * \\
(0.4607)\end{array}$ & $\begin{array}{l}1.6764 * * \\
(0.6124)\end{array}$ & $\begin{array}{l}0.6920 \\
(0.5076)\end{array}$ & $\begin{array}{l}0.3325 \\
(0.6689)\end{array}$ & $\begin{array}{l}1.8815^{* *} \\
(0.4345)\end{array}$ & $\begin{array}{l}1.3353 * * \\
(0.5884)\end{array}$ \\
\hline $\operatorname{lgpc}$ & $\begin{array}{l}1.5436 * * \\
(0.2878)\end{array}$ & $\begin{array}{l}1.8111 * * \\
(0.3633)\end{array}$ & $\begin{array}{l}0.9378 * * \\
(0.3571)\end{array}$ & $\begin{array}{l}1.7638 * * \\
(0.4849)\end{array}$ & $\begin{array}{l}0.0763 \\
(0.2658)\end{array}$ & $\begin{array}{l}0.1872 \\
(0.3680)\end{array}$ \\
\hline lexa & $\begin{array}{l}0.2512 * * \\
(0.1044)\end{array}$ & $\begin{array}{l}0.1176 \\
(0.1456)\end{array}$ & $\begin{array}{l}0.2467 * * \\
(0.1126)\end{array}$ & $\begin{array}{l}0.2355 \\
(0.1594)\end{array}$ & $\begin{array}{l}0.3193 * * \\
(0.1049)\end{array}$ & $\begin{array}{l}0.1906 \\
(0.1482)\end{array}$ \\
\hline limy & $\begin{array}{l}0.4954 * * \\
(0.2020)\end{array}$ & $\begin{array}{l}0.4976^{*} \\
(0.2675)\end{array}$ & $\begin{array}{l}0.6075^{* *} \\
(0.2330)\end{array}$ & $\begin{array}{l}0.5096 * \\
(0.3075)\end{array}$ & $\begin{array}{l}0.8664 * * \\
(0.1848)\end{array}$ & $\begin{array}{l}1.0990 * * \\
(0.2526)\end{array}$ \\
\hline lneer & $\begin{array}{l}-0.1065 * * \\
(0.0367)\end{array}$ & $\begin{array}{l}-0.1092 * \\
(0.0613)\end{array}$ & $\begin{array}{l}-0.1690 * * \\
(0.0394)\end{array}$ & $\begin{array}{l}-0.1220 * \\
(0.0661)\end{array}$ & $\begin{array}{l}-0.0270 \\
(0.0380)\end{array}$ & $\begin{array}{l}0.0404 \\
(0.0638)\end{array}$ \\
\hline corrupt & --- & $\begin{array}{l}-0.1283 * * \\
(0.0442)\end{array}$ & --- & $\begin{array}{c}-0.1566 * * \\
(0.0532)\end{array}$ & --- & $\begin{array}{l}-0.1086 * * \\
(0,0466)\end{array}$ \\
\hline pol & ---- & $\begin{array}{l}-0,2904 * * \\
(0.1481)\end{array}$ & --- & $\begin{array}{l}-0.4030 * * \\
(0.1630)\end{array}$ & --- & $\begin{array}{l}-0.2498 \\
(0.1633)\end{array}$ \\
\hline $\bar{R}^{2}$ & 0.88 & 0.88 & 0.72 & 0.73 & 0.56 & 0.65 \\
\hline
\end{tabular}

Standard errors are corrected for heteroskedasticity and autocorrelation. All regressions include fixed effects. Constant terms not reported. For variable definitions, see the data appendix.

A “**” (“*”) indicates statistical significance at the 5 percent (10 percent) level.

Standard errors are corrected for heteroskedasticity and autocorrelation. All regressions include fixed effects. Constant terms not reported. For variable definitions, see the data appendix. 


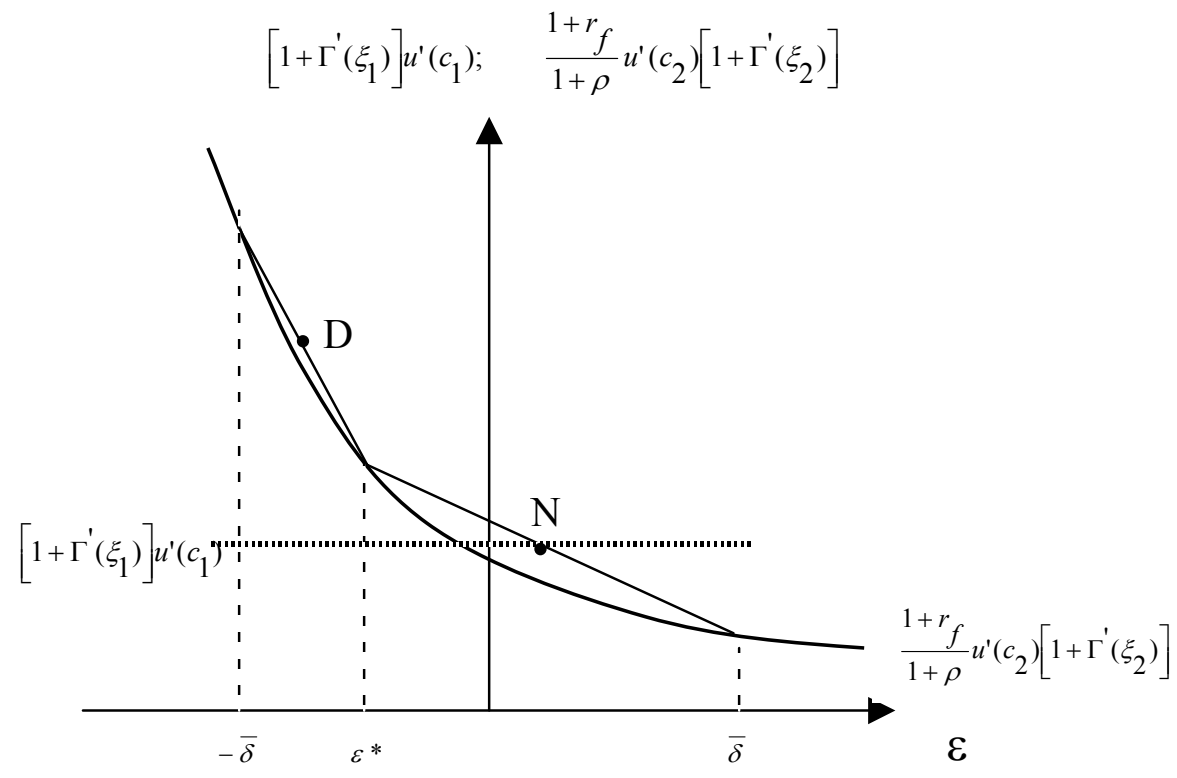

Figure 1

Marginal cost of public funds and optimal borrowing $[\mathrm{R}=0]$ 


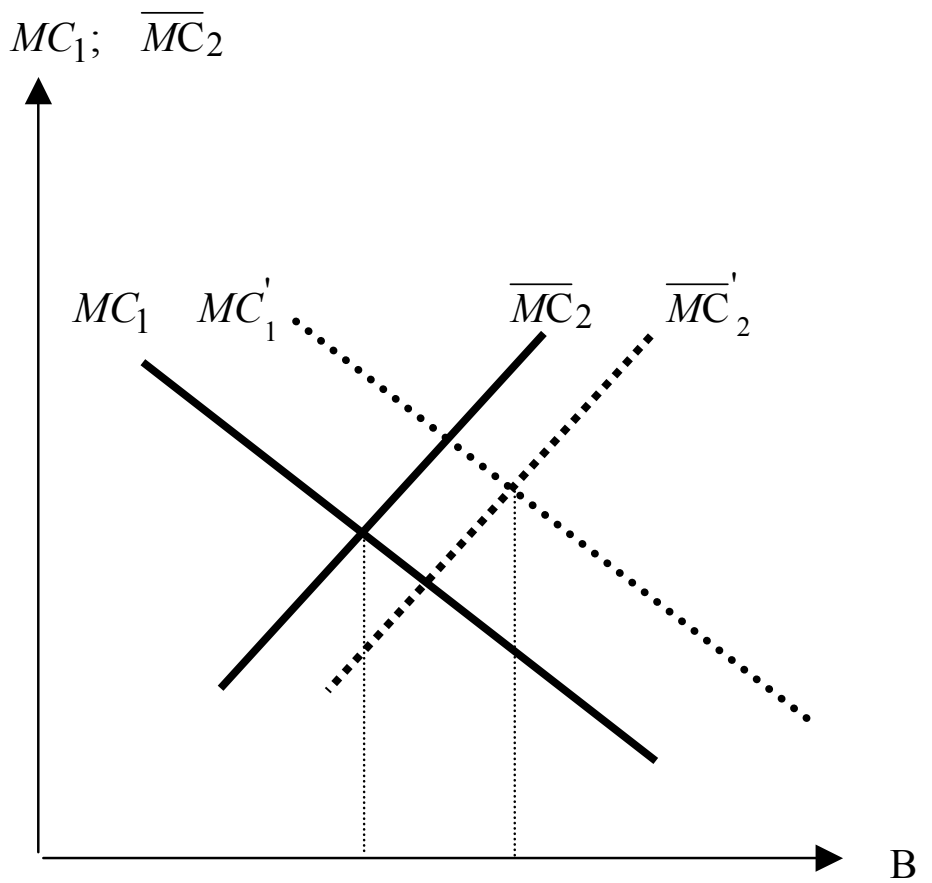

Figure 2

Marginal cost of public funds, international reserves and optimal borrowing. Higher R will shift both curves to the right, from the solid to the broken curves. 


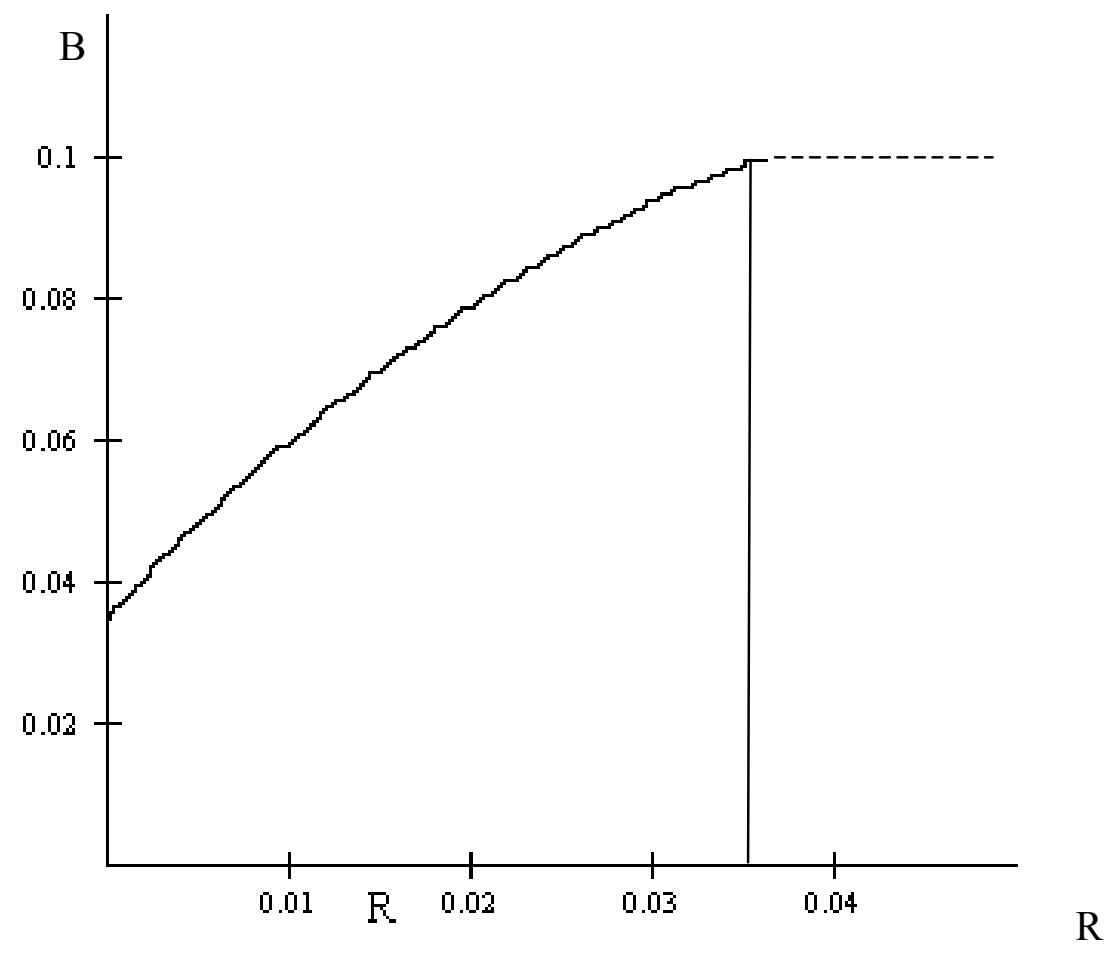

Figure 3

Optimal borrowing as a function of international reserves.

The simulation corresponds to the case of risk neutral agents, where $\alpha=0.1, \lambda=1.3, r_{f}=0, \rho=0.2, G=0.05, \bar{\delta}=0.2$ 


\section{Data Appendix}

$\mathrm{R} / \mathrm{P}=$ reserves minus gold, deflated by the U.S. GDP deflator (1995=100). Source: International Financial Statistics (IMF) for the reserves data and World Economic Outlook (IMF) for the deflator.

$\mathrm{R} /$ Debt $=$ reserves minus gold scaled by the sum of public and publicly-guaranteed external debt. Source: International Financial Statistics (IMF) for the reserves data and Global Development Finance (World Bank) for the debt figures.

$\mathrm{R} / \mathrm{M} 2$ = reserves minus gold scaled by broad money. Source: International Financial Statistics. Broad money is lines $34+35$ of IFS converted into millions of US dollars using the bilateral exchange rate.

lpop = total population, logged. Source: World Development Indicators.

$\operatorname{lgpc}=$ real GDP per capita, logged. Source: World Development Indicators.

lexa $=$ volatility of real export receipts, logged. Volatility is calculated using annual data and is the standard error of a regression of trend real exports. Source: International Financial Statistics.

limy $=$ the percentage share of imports in GDP, logged. Source: World Development Indicators.

lneer $=$ volatility of the nominal effective exchange rate, logged. Annual volatility is calculated using the previous 24 months of data and is the standard deviation of the innovation of the percentage change in the nominal effective exchange rate. Source: Information System Network, IMF.

corrupt $=$ corruption index based on the perception of foreign investors that high government officials will demand special payments or that illegal payments are expected throughout the lower levels of government in the forms of bribes connected with import and export licenses, exchange controls, tax assessment, polic protection, or loans. Source: International Country Risk Guide. The index ranges from 0 (most corrupt) to 6 (least corrupt). It has been re-scaled by multiplying it by 10/6 and for ease in interpreting results, the index has been multiplied by minus one so that higher values of the index imply higher corruption.

pol $=$ the probability of a leadership change by constitutional means. Source: LaBlang (2000).

Countries: The 137 countries listed in the World Bank's Global Development Finance data set. 